\title{
PAPILIO ARCESILAUS.
}

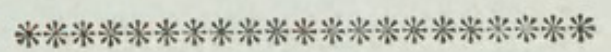

CHARACTER GENERICUS.

Antenne apicem versus crassiores, sæpius clavato-capitatæ.

Ala (sedentis) erectæ sursumque conniventes, (volatu diurno.)

$$
\text { Lin. Syst. Nat. p. } 744 .
$$

CHARACTER SPECIFICUS, छ'.

PAPILIO alis falcatis nigris, primoribus fascia transversa fulva maculaque ad apicem nivea.

PAPILIO ARCESILAUS.

Cram. t. 294.

PAPILIO Chorinæus. P. alis integerrimis fuscis, anterioribus falcatis, fascia fulva, posterioribus caudatis.

Fabr.sp. ins. 2. p. 60 .

Americam Australem, præcipue Surinamiam incolit Papilio Arcesilaus, cujus veram magnitudinem ostendit tabula. 




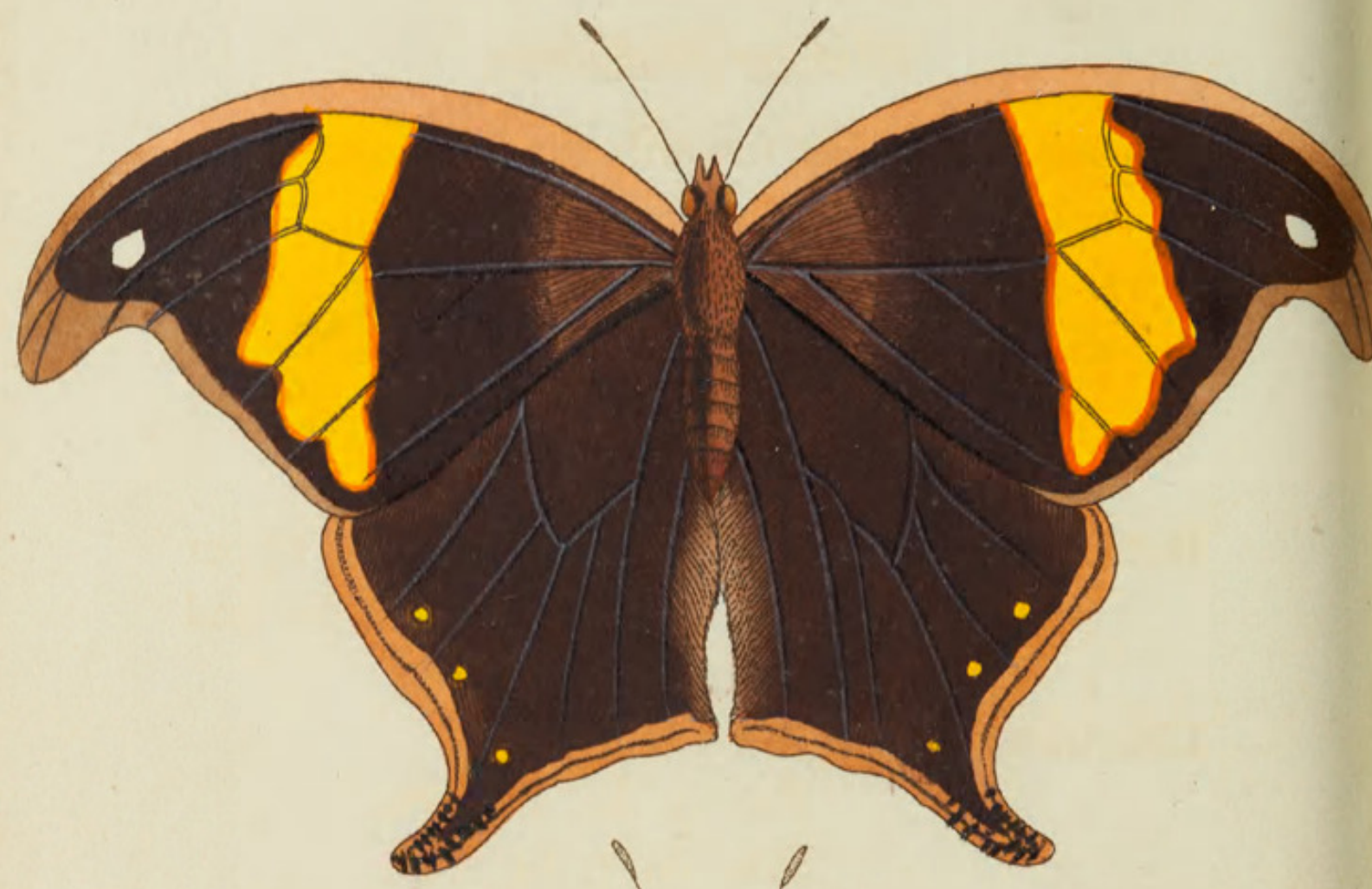

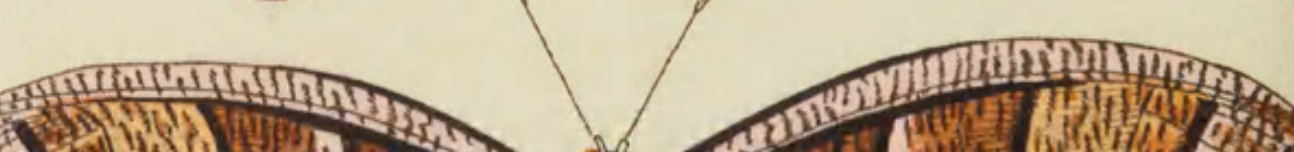

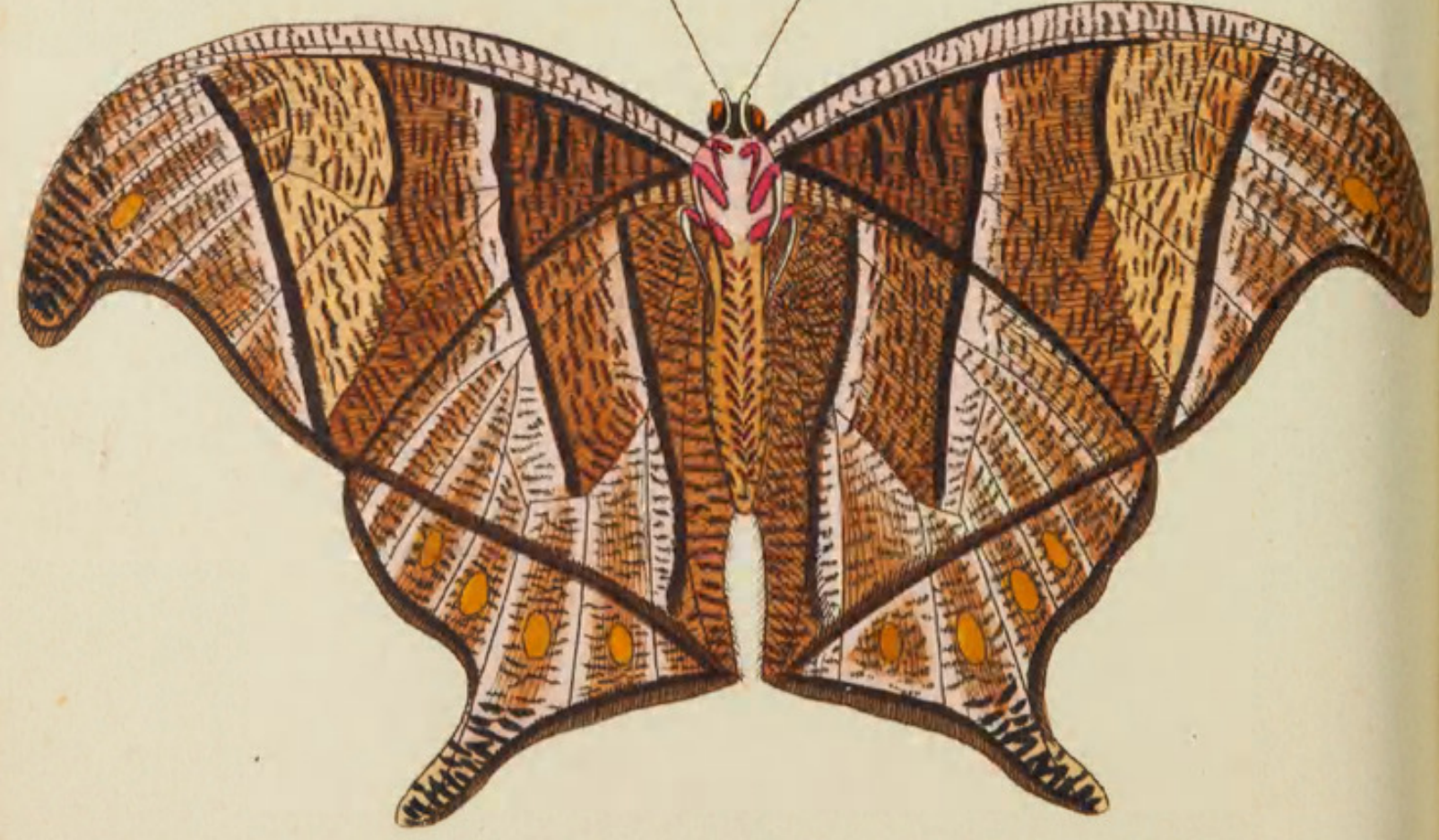

ล2NDde Dof tolutp: 


\section{ARCESILAUS.}

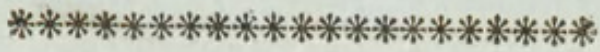

GENERIC CHARACTER.

Antenna thickening towards the end, and commonly terminating in a clavated tip.

Wings (when at rest) meeting upwards; (llight diurnal.)

\section{SPECIFIC CHARACTER, E'C.}

Butterfly with falcated black wings, the upper pair marked by a transverse fulvous bar and a white speck near the tip.

Chorinæus.

$$
\begin{aligned}
& \text { Fab. sp. ins. 2. p. } 60 . \\
& \text { Sulz. ins. t. 14. f. } 4 . \\
& \text { Lin. Syst. Nat. Gmel. p. } 2281 .
\end{aligned}
$$

The species represented on the present plate is exhibited in its natural size, and is a native of SouthAmerica, particularly of Surinam. 


\section{$2 \mathrm{BHL}$ Biodiversity Heritage Library}

Shaw, George. 1805. "Arcesilaus, Papilio arcesilaus [PI. 716]." The Naturalist's Miscellany 17(CXCIII), https://doi.org/10.5962/p.311153.

View This Item Online: https://www.biodiversitylibrary.org/item/281954

DOI: https://doi.org/10.5962/p.311153

Permalink: https://www.biodiversitylibrary.org/partpdf/311153

\section{Holding Institution}

Museums Victoria

\section{Sponsored by}

Atlas of Living Australia

\section{Copyright \& Reuse}

Copyright Status: Public domain. The BHL considers that this work is no longer under copyright protection.

This document was created from content at the Biodiversity Heritage Library, the world's largest open access digital library for biodiversity literature and archives. Visit BHL at https://www.biodiversitylibrary.org. 